\title{
Correction: Evaluation of pulmonary dysfunctions and acid-base imbalances induced by Chlamydia psittaci in a bovine model of respiratory infection
}

\author{
Carola Ostermann ${ }^{1 \dagger}$, Susanna Linde ${ }^{1 \dagger}$, Christiane Siegling-Vlitakis ${ }^{2}$ and Petra Reinhold ${ }^{1 *}$
}

\section{Correction}

Following publication of our article [1], we noticed the following mistakes:

Firstly, the numbers in the headings of the additional files have been reversed. In Additional file 2, cell A1 should read "Additional file 2: Concentrations of plasma glucose, L-lactate, sodium, potassium, chloride, and calculated strong ion difference (SID)" rather than "Additional file 3: Concentrations of plasma glucose, L-lactate, sodium, potassium, chloride, and calculated strong ion difference (SID)". In Additional File 3, cell A1 should read "Additional file 3: Concentrations of inorganic phosphate and total protein, results of electrophoresis, and calculated values for (Atot)" rather than "Additional file 2: Concentrations of inorganic phosphate and total protein, results of electrophoresis, and calculated values for (Atot)".

Secondly, in the legend of Figure 2 the term "d a.i." is not an abbreviation of "days after inoculation" and should instead read "days ante inoculationem".

\section{Author details}

${ }^{1}$ Institute of Molecular Pathogenesis at 'Friedrich-Loeffler-Institut' (Federal Research Institute for Animal Health), Naumburger Str. 96a, 07743 Jena, Germany. ${ }^{2}$ Freie Universität Berlin, Faculty of Veterinary Medicine, Oertzenweg 19b, 14163 Berlin, Germany.

Received: 16 July 2014 Accepted: 16 July 2014 Published: 6 August 2014

\section{Reference}

1. Ostermann C, Linde S, Siegling-Vlitakis C, Reinhold P: Evaluation of pulmonary dysfunctions and acid-base imbalances induced by Chlamydia psittaci in a bovine model of respiratory infection. Multidiscip Respir Med 2014, 9:10.

\section{doi:10.1186/2049-6958-9-42}

Cite this article as: Ostermann et al:: Correction: Evaluation of pulmonary dysfunctions and acid-base imbalances induced by Chlamydia psittaci in a bovine model of respiratory infection. Multidisciplinary Respiratory Medicine 2014 9:42.

\footnotetext{
* Correspondence: petra.reinhold@fli.bund.de

${ }^{\dagger}$ Equal contributors

${ }^{1}$ Institute of Molecular Pathogenesis at 'Friedrich-Loeffler-Institut' (Federal Research Institute for Animal Health), Naumburger Str. 96a, 07743 Jena, Germany
}

Submit your next manuscript to BioMed Central and take full advantage of:

- Convenient online submission

- Thorough peer review

- No space constraints or color figure charges

- Immediate publication on acceptance

- Inclusion in PubMed, CAS, Scopus and Google Scholar

- Research which is freely available for redistribution

\section{Biomed Central}

(c) 2014 Ostermann et al.; licensee BioMed Central Ltd. This is an Open Access article distributed under the terms of the Creative Commons Attribution License (http://creativecommons.org/licenses/by/4.0), which permits unrestricted use, distribution, and reproduction in any medium, provided the original work is properly credited. The Creative Commons Public Domain Dedication waiver (http://creativecommons.org/publicdomain/zero/1.0/) applies to the data made available in this article, unless otherwise stated. 